\title{
Evaluasi Kualitatif Terapi Antibiotik pada Pasien Pneumonia di Rumah Sakit Pendidikan Surabaya Indonesia
}

(Qualitatif analysis of antibiotic therapy in pneumonia patient in Teaching Hospital Surabaya Indonesia)

\author{
Ana Khusnul Faizah*, \& Oki Nugraha Putra \\ Program Studi Farmasi, Fakultas Kedokteran Universitas Hang Tuah, Jl. Arief Rachman Hakim No.150, Jawa Timur, \\ Indonesia
}

\begin{abstract}
Pneumonia is one of the the most common illness in hospitalized patients and the highest mortality in hospitalized patients in Indonesia. Antibiotics are major drug prescribed for pneumonia patient. Irrational usage of antibiotics can increase antibiotic resistance, morbidity, mortality and health cost. Antibiotic usage is evaluated by qualitative and quantitative. The objective of this study is to evaluate antibiotic therapy qualitatively in pneumonia patient who hospitalized at dr. Soetomo Hospital. This study was held by cohort prospective method and analyzed with Gyssens method. Number of medical record, name of patient, age, gender, weight, diagnose, therapy, dosage regimen and rute of therapy were assessed from medical record. There were 47 patients with pneumonia who include in this study. The patients were 0-24 months (21\%); $2-12$ years old (4\%); 13-59 years old (49\%) dan $>59$ years old (26\%). Top five antibiotics in this study were ceftazidime (20\%), levofloxacin (18\%) dan ceftriaxone (14\%). This study found 3 patients (6\%) IVA category (more effective); 1 patients (2\%) IIA category (dose) dan 3 patients (6\%) IIIA category (duration). Pharmacist has role to increase quality life of patients.
\end{abstract}

Keywords: antibiotic; evaluation of antibiotic; qualitative analysis; gyssens; therapy; pneumonia.

ABSTRAK: Penggunaan antibiotik yang tidak rasional dapat meningkatkan angka resistensi antibiotik, morbiditas, mortalitas dan biaya kesehatan. Evaluasi penggunaan antibiotik dapat dilakukan secara kualitatif dan kuantitatif. Tujuan dari penelitian ini adalah evaluasi penggunaan antibiotik secara kualitatif pada pasien pneumonia di RSUD dr. Soetomo Surabaya. Penelitian ini dilakukan secara kohort prospektif pada pasien pneumonia yang menjalani rawat inap di RSUD dr. Soetomo selama 4 bulan dan dievaluasi denga metode Gyssens. Data diambil dari rekam medik pasien berupa nomer rekam medik, nama pasien, usia, berat badan, diagnosis, data klinik, data laboratorium, terapi, dosis, rute pemberian dan interval terapi. Dari hasil penelitian diperoleh 47 pasien pneumonia, termasuk pneumonia komunitas, pneumonia nosokomial dan bronkopneumonia. Pasien berusia mulai dari 0-24 bulan (21\%); 2-12 tahun (4\%); $13-59$ tahun (49\%) dan $>59$ tahun (26\%). Lima besar antibiotik yang digunakan adalah seftazidim (20\%), levofloksasin (18\%) dan seftriakson (14\%). Dalam peneitian ini menunjukkan 3 pasien (6\%) kategori IVA (alternatif lebih efektif); 3 (6\%) pasien kategori IIIA (pemberian terlalu lama) dan 1 pasien (2\%) kategori IIA (dosis tidak tepat). Apoteker berperan dalam evaluasi antibiotika untuk meningkatkan kualitas hidup pasien.

Kata kunci: antibiotik; evaluasi antibiotika; gyssens; terapi; evaluasi kualitati; pneumonia.

\section{Pendahuluan}

Infeksi termasuk dalam sepuluh penyakit terbanyak di Indonesia, sehingga terapi antibiotik cukup tinggi. Semakin tingginya penggunaan antibiotik dapat menyebabkan peningkatan penggunaan antibiotik irrasional. Penggunaan antibiotik irrasional salah satunya yaitu penggunaan tanpa resep. Data yang diperoleh WHO menunjukkan bahwa 64\% Negara di Asia Tenggara memberikan antibiotik tanpa resep [1]. Penelitian tim AMRIN di dua rumah sakit pendidikan di Indonesia mendapatkan hanya $21 \%$ peresepan antibiotik yang tergolong rasional [2]. Penggunaan antibiotik irrasional dapat meningkatkan angka resistensi bakteri terhadap antibiotik. Hasil penelitian Antimicrobial Resistant in Indonesia (AMRINStudy) tahun 2000-2005 pada 2494 individu di masyarakat, memperlihatkan bahwa 43\% Escherichia coli resisten terhadap berbagai jenis antibiotik antara lain ampisilin (34\%), kotrimoksazol (29\%) dan kloramfenikol (25\%).

Tingginya angka resistensi antibiotik di Indonesia menjadi permasalahan penting di bidang kesehatan karena dapat meningkatkan morbiditas, mortalitas dan biaya kesehatan. Oleh karena itu, Kementerian

\section{Article history}

Received: 30 Mar 2019 Accepted: 10 Jun 2019 Published: 20 Agust 2019

Access this article

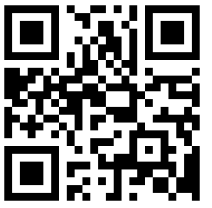


Kesehatan mengeluarkan Permenkes Nomor 8 Tahun 2015 Tentang Program Pengendalian Resistensi Antimikroba Di Rumah Sakit [3]. Didalam Permenkes tersebut mencantumkan bahwa apoteker memiliki peran dalam penerapan penggunaan antibiotik secara bijak melalui pelayanan farmasi klinik. Kegiatan tersebut didukung Permenkes Nomor 58 Tahun 2014 Tentang Standar Pelayanan Kefarmasian Di Rumah Sakit salah satu pelayanan farmasi klinik yaitu evaluasi penggunaan obat [4].

Pneumonia adalah penyakit yang ditandai dengan peradangan parenkim paru disebabkan oleh mikroorganisme (bakteri, jamur, virus, parasit), bahan kimia, radiasi, obat dan lain-lain [5]. Di Indonesia, pneumonia termasuk dalam 10 besar penyakit terbanyak pada pasien rawat inap di rumah sakit di Indonesia pada tahun 2011 dan menempati angka kematian tertinggi dari 10 besar penyakit terbanyak pada rawat inap di rumah sakit Indonesia [6]. Antibiotik empirik merupakan pengobatan awal pada pasien pneumonia. Penundaan pemberian antibiotika lebih dari 4 jam dapat meningkatkan risiko kematian [7].

Evaluasi penggunaan antibiotik dil lakukan secara kuantitatif dan kualitatif. Evaluasi secara kuantitatif dapat dilakukan dengan rumus DDD per 100 hari rawat (DDD per 100 bed days), untuk evaluasi jenis dan jumlah antibiotik yang digunakan. Evaluasi secara kualitatif dapat dilakukan antara lain dengan metode Gyssens, untuk evaluasi ketepatan penggunaan antibiotik [8]. Penelitian ini bertujuan untuk evaluasi penggunaan antibiotic secara kualitatif pada pasien pneumonia menggunakan metode Gyssens.

\section{Metode Penelitian}

\section{Lokasi Penelitian}

Penelitian ini merupakan penelitian kohort prospektif terhadap pasien dewasa dan anak yang dirawat di RS Pendidikan Surabaya. Kriteria inklusi pada penelitian adalah pasien dengan diagnosa Pneumonia dan mendapatkan terapi antibiotika selama dirawat di RS. Sampel meliputi pasien yang menjalani rawat inap di RS Pendidikan Surabaya selama periode Maret-Juni dan memenuhi kriteria inklusi.

\section{Data Penelitian}

Dari rekam medik pasien dicatat data pasien meliputi nomor rekam medik, usia, jenis kelamin, berat badan, diagnosa, penyakit penyerta/komplikasi, data laboratorium, data klinik, riwayat alergi, dan terapi obat yang diterima meliputi jenis obat, dosis, rute pemberian, frekuensi pemberian, lama pemberian.

\section{Analisis Data}

Antibiotika yang diberikan pada pasien dievaluasi secara kualitatif dengan metode Gyssens. Alur dari metode Gyssens dapat dilihat pada Gambar 1.

\section{Hasil dan Diskusi}

Jumlah pasien pneumonia yang masuk dalam penelitian sebanyak 47 pasien. Karakterisitk pasien pneumonia tercantum pada Tabel 1 menunjukkan jumlah pasien laki-laki (55\%) lebih banyak diandingkan pasien perempuan $(45 \%)$. Rentang usia pasien pneumonia mulai dari 0-24 bulan (21\%); 2-12 tahun (4\%); $13-59$ tahun $(49 \%)$ dan $>59$ tahun (26\%). Diagnosa pasien antara lain pneumonia komuniti (68\%); pneumonia nosokomial (11\%) dan bronkopneumonia (21\%).

Tabel 1. Karakteristik Pasien

\begin{tabular}{lc}
\hline \multicolumn{1}{c}{ Kategori } & Jumlah (\%) \\
\hline Jenis Kelamin & $26(55)$ \\
Laki-laki & $21(45)$ \\
Perempuan & \\
Usia (tahun) & $10(21)$ \\
0-24 bulan & $2(4)$ \\
2-12 & $23(49)$ \\
13-59 & $12(26)$ \\
$>59$ & \\
Diagnosa & $32(68)$ \\
Pneumonia komuniti & $9(21)$ \\
Bronkopneumonia & $7(11)$ \\
Pneumonia noskomial &
\end{tabular}

Antibiotika yang digunakan pada pasien pneumonia yang termasuk dalam subyek penelitian dapat dilihat pada Tabel 2. Pemilihan terapi antibiotik pasien pneumonia sebaiknya berdasarkan data mikroorganisme dan uji kepekaan, tetapi ada beberapa hal yang menjadi kendala seperti pneuomia berat yang dapat mengancam jiwa, bakteri patogen yang diisolasi belum tentu penyebab pneumonia dan dibutuhkan waktu untuk membiakkan bakteri dalam uji kepekaan. Oleh karena itu, pasien pneumonia mendapat terapi empiris yang didasarkan pada bakteri penyebab pneumonia [9]. 


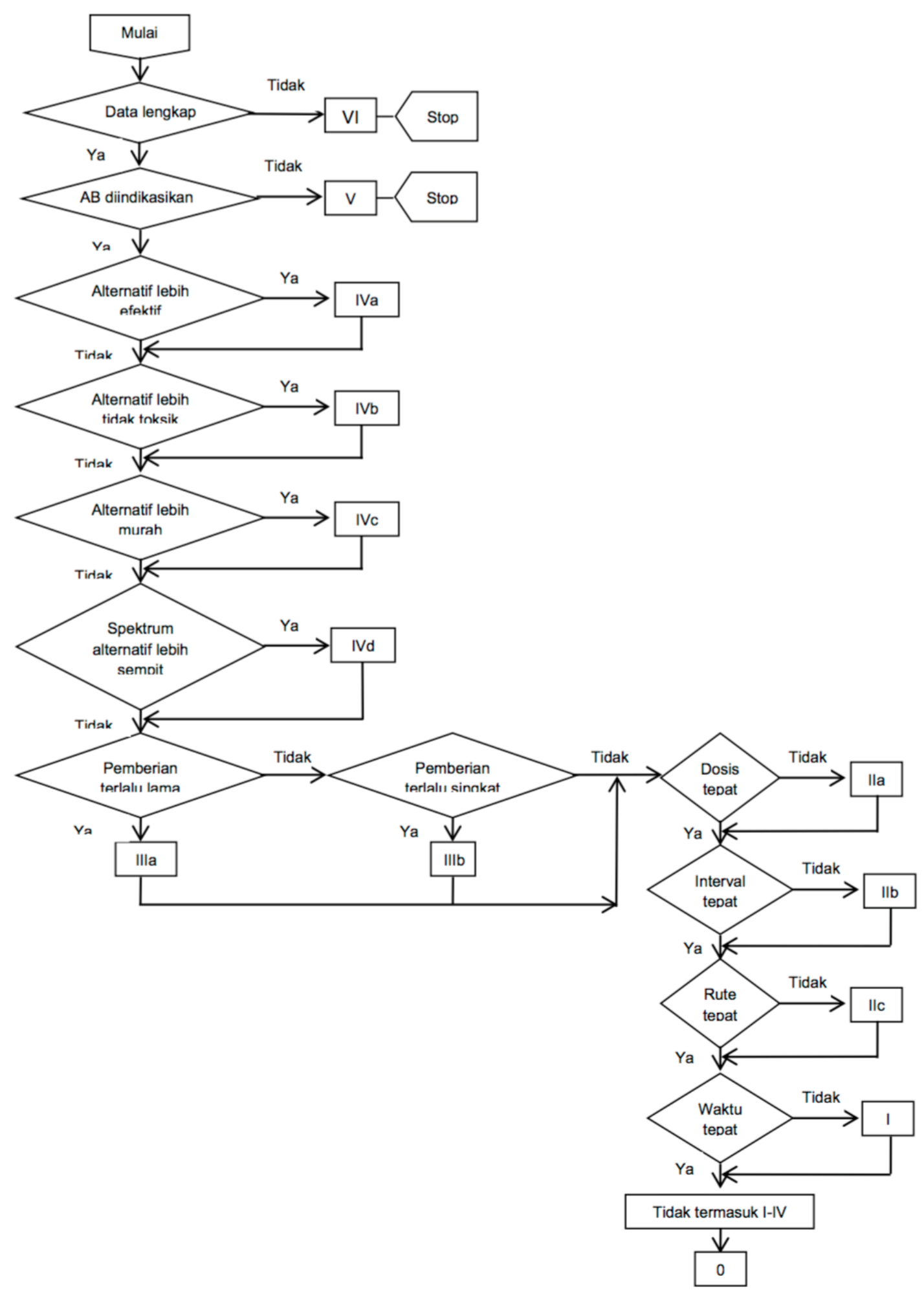

Gambar 1. Evaluasi Antbiotika secara Kualititatif dengan Metode Gyssens 
Berdasarkan hasil evaluasi kualitatif antibiotika dengan metode Gyssens diperoleh hasil yang tercantum pada Tabel 3. Antibiotika yang diberikan pada pasien diberikan secara empiris selama 3 hari. Apabila ada perbaikan kondisi pasien, maka antibiotik dilanjutkan sampai 7-14 hari. Apabila tidak ada perbaikan, maka dilakukan penggantian antibiotik sesuai dengan data mikrobiologi dan uji kepekaan. Antibiotika yang diberikan pada pasien sudah sesuai dengan Pedoman Terapi Pasien Pneumonia yang disusun oleh Persatuan Dokter Paru Indonesia dan diterbitkan tahun 2003.

Tabel 2. Daftar Antibiotika pada Pasien Pneumonia

\begin{tabular}{lc}
\hline \multicolumn{1}{c}{ Nama Antibiotika } & Jumlah (\%) \\
\hline Seftazidim & $14(20)$ \\
Levofloksasin & $13(18)$ \\
Seftriakson & $10(14)$ \\
Ampisillin-sulbaktam & $9(13)$ \\
Gentamisin & $5(7)$ \\
Sefotaxim & $4(6)$ \\
Siprofloksasin & $4(6)$ \\
Amikasin & $3(4)$ \\
Cotrimoxazole & $3(4)$ \\
Amoxicillin-clavulanat & $1(1)$ \\
Erithromisin & $1(1)$ \\
Cefoperazone sulbaktam & $1(1)$ \\
\hline Kloramfenikol & $1(1)$ \\
\hline
\end{tabular}

Tabel 3. Evaluasi Antibiotika secara Kualitatif pada Pasien Pneumonia dengan Metode Gyssens

\begin{tabular}{lc}
\hline \multicolumn{1}{c}{ Kategori Gysens } & Jumlah (\%) \\
\hline Tidak termasuk I-IV & $39(82,9)$ \\
IIA & $2(4,3)$ \\
IIIA & $3(6,4)$ \\
IVA & $3(6,4)$ \\
\hline
\end{tabular}

Hasil evaluasi kualitatif antibiotika dengan metode Gyssens diperoleh 3 (6,4\%) pasien yang termasuk kategori IVA (alternatif antibiotika lebih efektif); 3 (6,4\%) pasien kategori IIIA (durasi antibiotika terlalu lama) dan 2 (4,3\%) pasien kategori IIA (dosis tidak sesuai). Penemuan dari studi ini sebanding dengan studi yang dilakukan di RSUD dr Moewardi Surakarta yang menunjukkan kategori
IVA merupakan jumlah terbesar dalam evaluasi dengan metode Gyssens [10]. Berbanding terbalik dengan studi yang dilakukan di ICU anak yang tidak menemukan kasus kategori IVA pada evaluasi antibiotika dengan metode Gyssens [11].

Pasien dengan kategori IVA merupakan pasien anak. Dua dari pasien tersebut merupakan pasien imunokompromis dan gizi buruk yang masing-masing mendapat terapi amikasin dan ampisillin-sulbaktam. Berdasarkan Pedoman Diagnosis dan Terapi SMF Ilmu Kesehatan Anak direkomendasikan pemberian antibiotika golongan sefalosporin generasi ketiga [12]. Gizi buruk dapat mempengaruhi prognosis pasien pneumonia. Sefalosporin generasi ketiga sebaiknya diberikan bila S. pneumoniae memiliki MIC> 2 mikrogram/mL, apabila pasien alergi terhadap golongan penisilin dapat diberikan klindamisin [13]. Pasien lain dari kategori IVA mendapat terapi sefotaksim pada hari pertama sampai kelima, sedangkan pada hari ketiga terdapat hasil uji kepekaan bahwa resisten terhadap sefotaksim. Rekomendasi dari kami diganti dengan antibiotika yang sensitif sesuai hasil uji kepekaan.

Kategori kedua yang kami temukan berdasarkan metode Gyssens adalah kategori IIA. Pasien dewasa yang berusia 78 tahun dengan $\mathrm{BB}<40 \mathrm{~kg}$ mendapat gentamisin 2x160 mg. Dosis gentamisin berdasarkan pustaka adalah 4-7 mg/kg/hari, sehingga dosis gentamisin yang seharusnya diperoleh pasien adalah 160-280 mg/ hari [14]. Pemberian gentamisin perlu monitoring fungsi ginjal untuk menghindari nefrotoksik dari gentamisin. Pasien mendapatkan terapi gentamisin, ceftazidime dan albumin 20\% selama di RS. Tidak ditemukan interaksi obat merugikan pada pasien.

Kategori terakhir yang diperoleh adalah kategori IIIA. Pasien pertama mendapat ampisillin-sulaktam $>10$ hari, pasien kedua mendapat seftriakson selama 7 hari dan pasien terakhir mendapat seftriakson $>14$ hari tetapi tidak ada perbaikan pada pasien. Rekomendasi dari kami dilakukan uji mikrobiologi dan antibiotik diganti sesuai dengan hasil uji kepekaan.

Pasien yang tidak membaik dengan antibiotika empiris ditinjau dari segi obat dan bakteri dapat disebabkan obat tidak tepat, dosis/ cara pemberian tidak tepat, interaksi obat, bakteri resisten terhadap antibiotik, mikrobakteria atau nokardia atau bakteri penyebab nonbakterial (jamur atau virus). Penggunaan antibiotika di RS Pendidikan Surabaya dilakukan evaluasi secara berkala oleh apoteker yang bekerja sama dengan dokter dan perawat untuk meningkatkan kualitas hidup pasien dan meminimalkan resistensi antibiotika. 
Outcome pasien pada penelitian ini 81\% KRS dengan kondisi sembuh dari pneumonia. Beberapa pasien KRS melanjutkan terapi antibioatika dengan antibiotika oral. Lama perawatan di RS tidak dianalisis pada penelitian, sehingga hal tersebut menjadi keterbatasan penelitian kami.

Rekomendasi yang dibuat peneliti disampaikan kepada apoteker klinis di ruangan untuk didiskusikan dan diteruskan kepada dokter yang merawat pasien. Kegiatan visite bersama yang dilakukan oleh dokter, perawat dan apoteker dapat dilakukan untuk membahas terapi atau perawatan yang diberikan pada pasien, sehingga dapat menemukan atau mencegah terjadinya permasalahan serta dapat meningkatkan kualitas hidup pasien.

\section{Kesimpulan}

Evaluasi antibiotik secara kualitatif dengan metode Gyssens diperoleh 3 pasien (6\%) kategori IVA (alternatif lebih efektif); 3 (6\%) pasien kategori IIIA (pemerian terlalu lama) dan 1 pasien (2\%) kategori IIA (dosis tidak tepat).

\section{Referensi}

[1] World Health Organization. (2015). Worlwide country situation analysis: response to antimicrobial resistance. Geneva, Switzerland: World Health Organization.

[2] Hadi, U., Keuter, M., Asten, H. v., \& Broek, P. v. (2008, Juli). Chapter VII Optimizing antibiotic usage in adult admitted with fever by a multifaceted intervention in an Indonesian governmental hospital. Tropical Medicine and International Health , 13(7), 888-99.
[3] Moelok, N. F. (2015, Februari 11). Peraturan Menteri Kesehatan Republik Indonesia No 8 Tahun 2015. Tentang Program Pengendalian Resistensi Antimikroba di Rumah Sakit Jakarta, Indonesia: Menteri Kesehatan Republik Indonesia.

[4] Mboi, N. (2014, Agustus 18). eraturan Menteri Kesehatan Republik Indonesia No 58 Tahun 2014. Tentang Standar Pelayanan Kefaramasian di Rumah Sakit. Jakarta, Indonesia: Menteri Kesehatan Republik Indonesia.

[5] Loscalzo, J. (2010). Harrison's Pulmonary and Critical Care Medicine. New York, United States: McGraw Hill .

[6] Kementerian Kesehatan Republik Indonesia. (2012). Profil Kesehatan Indonesia Tahun 2011. Jakarta, Indonesia: Kementerian Kesehatan Republik Indonesia.

[7] Christ-Crain, M., STolz, J., ingisser, R., \& Gencay, M. (2004, Februari 21). Effect of procalcitonin-guided treatment on antibiotic use and outcome in lower respiratory tract infections: cluster-randomised, single-blinded intervention trial. Lancet, 363(9409), 600-7.

[8] Kementerian Kesehatan Republik Indonesia. (2011). Pedoman Pelayanan Kefarmasian Untuk Terapi Antibiotik. Jakarta, Indonesia: Kementerian Kesehatan Republik Indonesia.

[9] Perhimpunan Dokter Paru Indonesia. (2003). Pneumonia Komuniti Pedoman Diagnosis \& Penatalaksanaan di Indonesia. Jakarta, Indonesia: Perhimpunan Dokter Paru Indonesia.

[10] Marsono, Y. (2015, Juli 13). Evaluasi Penggunaan Antibiotik Pada Pasien Pneumonia Dengan Metode Gyssens Di Instalasi Rawat Inap Rumah Sakit Umum Daerah Dokter Moewardi Surakarta Tahun. Dipetik Juli 31, 2017, dari UMS ETD-db: http://eprints.ums. ac.id/34808/

[11] Yuniar, I., Karyanti, M. R., Tambunan, T., \& Rizkiyani, N. A. (2013, April). Evaluasi Penggunaan Antibiotik dengan Kartu Monitoring Antibiotik Gyssens. Sari Pediatri, 14(6), 384-90.

[12] Setiawati, L., Setyaningrum, R., \& Makmuri, M. (2008). Pedoman Diagnosis dan Terapi Bagian/ SMF IImu Kesehatan Anak ed III RSUD dr Soetomo. Surabaya, Indonesia: Fakultas Kedokteran Universitas Alrlangga.

[13] Long, S. S., Pickering, L. K., \& Prober, C. (2012). Principles and Practice of Pediatric Infectious Diseases 4th ed. Toronto, United States: Elsevier Saunders.

[14] American Pharmacists Association. (2016). Drug Information Handbook (25 ed.). North America: Wolters Kluwer. 